\title{
PRODUCTION ENGINEERING CURRICULUM IN INDUSTRY 4.0 IN A BRAZILIAN CONTEXT
}

\author{
R.G. Souza ${ }^{1 *}$, O. Quelhas ${ }^{1}$, G. Marchisotti ${ }^{1}$, J. Neto ${ }^{1}$, R. Anholon ${ }^{2} \&$ C. A. Marinho ${ }^{1}$
}

\section{ARTICLE INFO}

Article details

Submitted by authors 3 Sep 2018

Accepted for publication 8 Jul 2020

Available online $\quad 14 \mathrm{Dec} 2020$

\section{Contact details}

Corresponding author rgris@id.uff.br

\section{Author affiliations}

1 Federal Fluminense University, Rio de Janeiro, Brazil

2 University of Campinas, Campinas, São Paulo, Brazil

\section{$O R C I D \otimes$ identifiers}

R.G. Souza

https://orcid.org/0000-0003-1441-8638

O. Quelhas

https://orcid.org/0000-0001-6816-1677

G. Marchisotti

https://orcid.org/0000-0002-7028-0015

J. Neto

https://orcid.org/0000-0001-5974-7086

R. Anholon

https://orcid.org/0000-0003-3163-6119

C. Marinho

https://orcid.org/0000-0003-2347-5087

\section{DOI}

http: / /dx.doi.org/10.7166/31-4-2033
ABSTRACT

Industry 4.0 has been discussed in the scientific community since its inception in 2011. Discussions have focused on characterising what Industry 4.0 is. This industry will increasingly require professionals to perform complex and indirect tasks, such as working together with machines in their daily work. This article aims to analyse the skills and competencies required by Industry 4.0, and to compare them with the scope of production engineering disciplines in six Brazilian universities. As a methodological option, the study is classified as exploratory, bibliographic, and qualitative. It is established that the current syllabus of production engineering courses of Brazilian universities needs to be improved, seeking alignment with the skills and competencies required by Industry 4.0. Although the Industry 4.0 theme is being discussed in the scientific field in Brazilian universities, it is not yet possible to identify any key actions taken to adjust and improve production engineering courses.

\section{OPSOMMING}

Industrie 4.0 word al sedert die ontstaan daarvan in 2011 deur die wetenskaplike gemeenskap bespreek. Besprekings fokus op die karakterisering van wat presies Industrie 4.0 behels. Die industrie sal toenemend professionele persone benodig om ingewikkelde en indirekte take te voltooi, soos om daagliks saam met masjiene te werk. Die doel is om die vaardighede en bekwaamhede wat deur Industrie 4.0 benodig word te ontleed en om hulle te vergelyk binne die omvang van ses Brasiliaanse universiteite. Die ondersoek is geklassifiseer as verkennend, bibliografies en kwalitatief. Daar is vasgetel dat die bestaande sillabus van bedryfsingenieurswese van die ses universiteite verbeter moet word sodat daar beter belyning is met die benodigde vaardighede en bekwaamhede van Industrie 4.0. Alhoewel die Industrie 4.0-tema deur akademici by Brasiliaanse universiteite bespreek word, is dit nog nie moontlik om enige sleutel stappe om die bestaande bedryfsingenieurswese kursusse aan te pas te identifiseer nie.

\section{INTRODUCTION}

Innovation is the engine that increases industry's competitiveness. Over the centuries, industrial revolutions have taken place, ranging from the mechanisation of artisanal manufacturing to the automation of processes. Figure 1 summarises the four industrial revolutions.

The first industrial revolution occurred in England in the late eighteenth century, and was marked by innovation and the mechanisation of manual labour, focusing on increasing production through increased efficiency, speed, and quantity. This was in marked contrast with the practice that preceded it, in which production was carried out in an artisanal way. The first industrial revolution incorporated the concept of work into the concept of the factory system - pre-Fordism [1].

The second industrial revolution began in the mid-nineteenth century, and brought new sources of energy, the diffusion of the media (such as radio), and mass production. The focus of this period was on the development of scientific knowledge and the exploitation of the proletariat. It incorporated the concept of large stocks - Fordism [1]. 


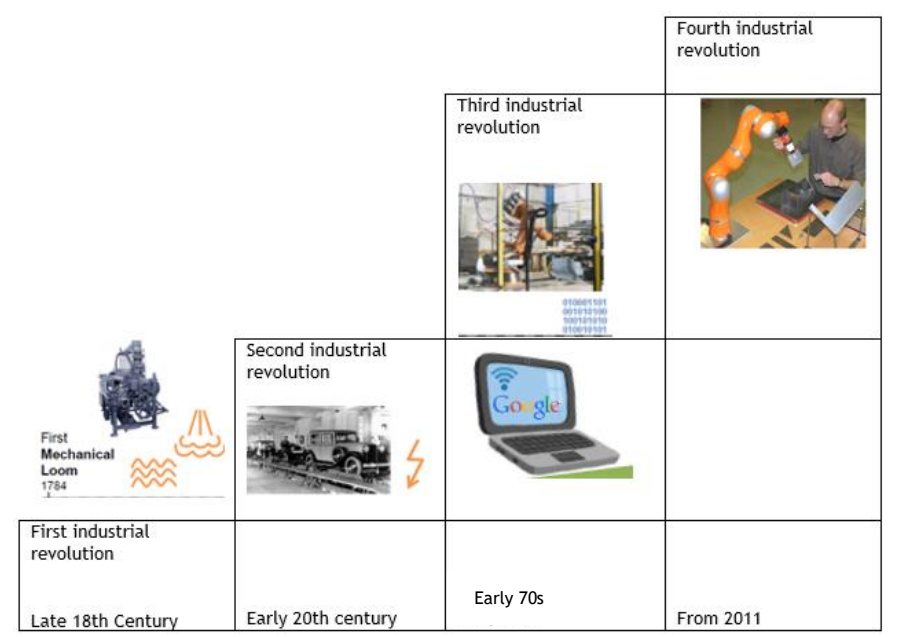

Figure 1: The four industrial revolutions

The third industrial revolution began in the mid-1970s, and was characterised by the progress of technologies and the computerisation of production systems. It incorporated the concepts of zero stock Toyota-ism' [1].

In 2011, at the Hannover Fair in Germany, a new concept emerged as part of the German government's strategy for developing high-tech manufacturing in the country. The term 'Industry 4.0' was thus created, from the German 'Industrie 4.0’ [2].

Industry 4.0, which is part of the fourth industrial revolution, is characterised by a set of changes in manufacturing processes, operations, and systems related to production, in which machines communicate directly without human intervention [3].

The concept of Industry 4.0 can be defined as the complete transformation of the entire sphere of industrial production through the fusion of digital technology and the internet with conventional industry [4].

Following the launch of Industry 4.0 in 2011, the number of academic papers and articles grew exponentially, jumping from 15 in 2011 to 12,588 in 2015, according to Germany's GENIOS database [5].

The emergence of Industry 4.0 has also interested academic institutions in possible changes to the academic background of young people in general, including learning technical and engineering topics in particular [6]. Today's students will deal with an increasingly globalised, automated, networked, and flexible world. The authors argue that, to achieve the objectives of Industry 4.0 (which will significantly transform work profiles), partnerships between industries and higher education institutions will be necessary. And, to prepare for Industry 4.0, it will be necessary to review the content of courses, especially technical topics.

With the challenges posed by Industry 4.0 and the new knowledge it requires, this article aims to analyse whether the curriculum and the subjects of the courses in production engineering of six Brazilian universities include the skills and competenciesthat would enable students to work in Industry 4.0. To achieve this goal, this article is supported by bibliometric research using the scientific method of an exploratory and qualitative study [7].

This article's secondary objective is to awaken the need for future research for the training of other technical professionals, in addition to allowing a reflection on the faculty in universities and educational institutions.

The next section presents the methodology used in this article to meet its primary objective. Section 3 presents the literature review, which will discuss the concepts of skills and competencies required by Industry 4.0, as well as the guidelines and disciplines for training production engineers at six Brazilian universities. Then, in Section 4 the gaps will be identified. Finally, the article discusses the results found.

Table 1 below sets out the elements identified as the focus of this study, the research problem, and the overall objective. 
Table 1: Identified elements, research problem, and overall objective

\begin{tabular}{|c|l|l|}
\hline $\begin{array}{l}\text { Identified } \\
\text { elements }\end{array}$ & \multicolumn{1}{|c|}{ Research problem } & \multicolumn{1}{c|}{ Overall objective } \\
\hline \multicolumn{1}{|c|}{ Skills } & $\begin{array}{l}\text { Do the undergraduate courses in production } \\
\text { engineering at six Brazilian universities } \\
\text { consider the skills and competencies required } \\
\text { Competencies } \\
\text { by Industry 4.0? }\end{array}$ & $\begin{array}{l}\text { Through a bibliographical review, identify the } \\
\text { skills and competencies required for Industry } \\
4.0, \text { seeking to identify gaps in the training of } \\
\text { production engineers. }\end{array}$ \\
\hline
\end{tabular}

\section{METHODOLOGY}

A systematic literature review was carried out using the SCOPUS and SCIENCE DIRECT databases. We used the keywords Industry 4.0, Production engineering, Skills, Qualification, Internet of Things, and Disciplines of production engineering. These keywords were defined by the authors because of their relevance to meeting the purpose of the article.

Table 2 shows the results for each of the key-word combinations that were carried out in January 2018.

Table 2: Keywords and the databases consulted (Source: Authors)

\begin{tabular}{|c|c|c|c|c|}
\hline \multicolumn{3}{|c|}{ KEY WORDS } & SCOPUS & $\begin{array}{l}\text { SCIENC } \\
\text { DIRECT }\end{array}$ \\
\hline \multicolumn{3}{|c|}{ INDUSTRY 4.0} & 4.220 & 30.475 \\
\hline & INDUSTRY 4.0 & $\begin{array}{l}\text { PRODUCTION } \\
\text { ENGINEERING }\end{array}$ & 109 & 343 \\
\hline & INDUSTRY 4.0 & SKILLS & 91 & 273 \\
\hline & INDUSTRY 4.0 & QUALIFICAT ION & 29 & 75 \\
\hline INDUSTRY 4.0 & $\begin{array}{l}\text { PRODUCTION } \\
\text { ENGINEERING }\end{array}$ & $\begin{array}{c}\text { DISCIPLINES OF } \\
\text { PRODUCTION ENGINEERING }\end{array}$ & 1 & 0 \\
\hline
\end{tabular}

After completing the searches for key words, the next step was to check which articles contained something relevant to training, skills, competencies, and training for Industry 4.0 in their abstracts. Using this filter, the number of articles was restricted to 39.

From the bibliographical research, and using only the keyword 'Industry 4.0', we noticed that the number of publications increased significantly in the years 2016 and 2017. In comparison, before 2013 the number of publications was less than 200.

Regarding the countries of publication, Germany, the pioneer of Industry 4.0, had the largest number of publications at 65 per cent - well ahead of the second-placed United States.

When we used the phrase 'Industry 4.0 and skills', we found five publications in the Scopus database, with only one of these publications [8] mentioning the debate about whether chemical engineers have the skills required by Industry 4.0 .

Production engineering has developed throughout the twentieth century in response to the need to develop methods and techniques to manage the productivity demanded by technological and market evolution.

In relation to the universities, six Brazilian public universities were selected as having the best ratings in their respective states [9]. 


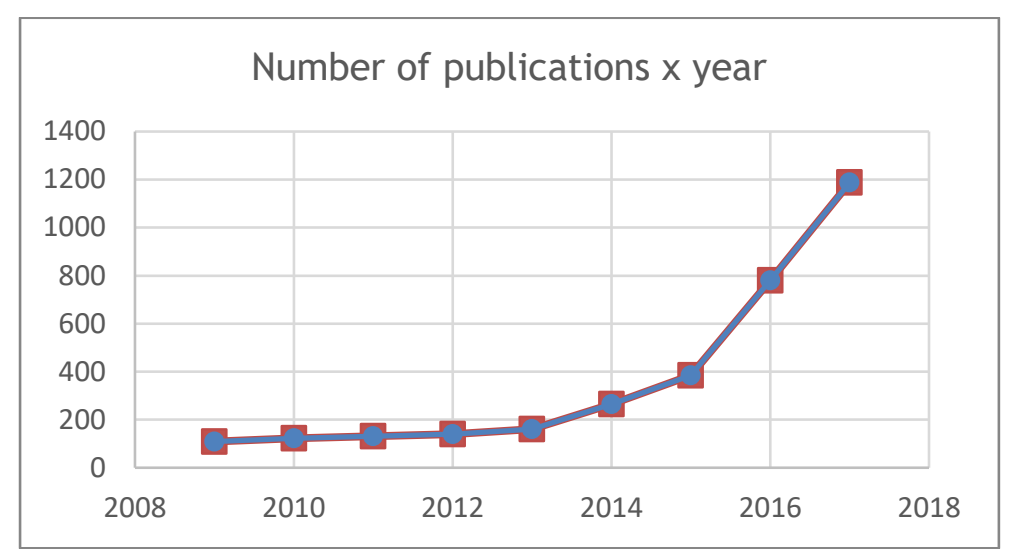

Figure 2: Number of publications per year (Source: Authors, with information from SCOPUS)

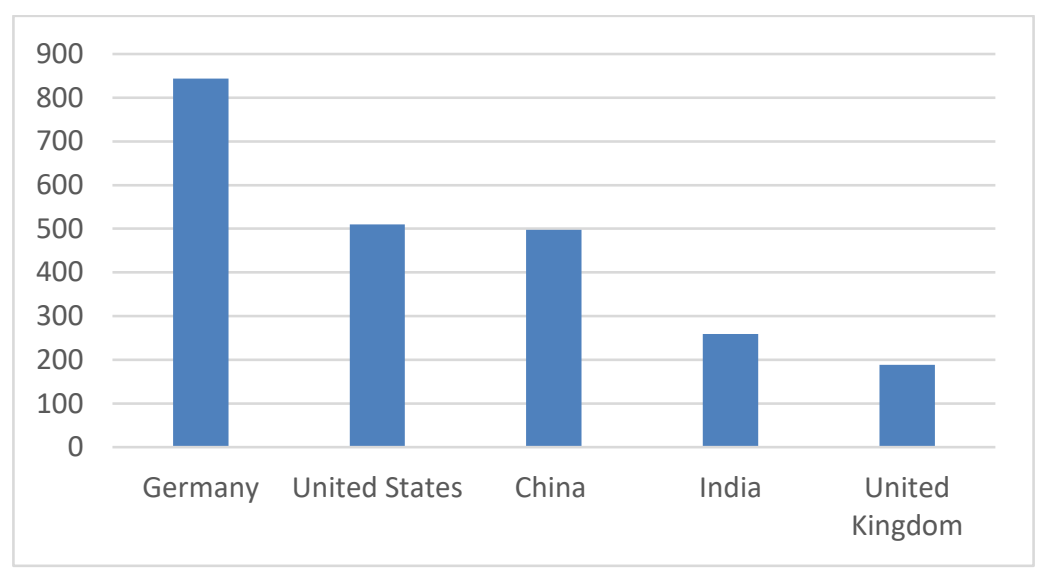

Figure 3: Country and number of publications (Source: Authors, with information from SCOPUS)

\section{LITERATURE REVIEW}

\subsection{Industry 4.0}

The focus of Industry 4.0 is to create intelligent products, procedures, and processes. Intelligent factories are the key feature in this structure. Industry 4.0 has to be implemented in an interdisciplinary way [6].

In Industry 4.0 the production systems will be highly flexible and adaptable, which is an important factor in being competitive in a market with small batches of customised products [10]. Automated mass production can become less economically feasible, especially when considering the environmental, social, and other costs.

Industry 4.0 requires a tight integration of physical components and IT systems for development and application, which requires specialists with in-depth knowledge to participate in the product development process [11]. The assembly lines will interact and be able to make decisions in real time, making the necessary adjustments to optimise production [3].

Intelligent manufacturing requires certain technologies to enable devices or machines to vary their behaviours in response to different situations and requirements, based on past experience and learning ability [12]. The machine can thus predict failure and autonomously trigger maintenance processes [2].

Authors who have published on Industry 4.0 always seek to define its scope in their articles. However, an expanded discussion on the need to improve the training of the workforce to work in the industry has not been seen yet.

One of the characteristics of Industry 4.0 is the ability to collect and use a large amount of data, allowing production systems to improve their decision-making and forecasting for the future [13]. 
With the changes that will accompany the transformation of the industrial age, there is a high probability that new risks will have a negative impact on many company aspects. These risks are related to information security, such as cyber attacks, malware, spyware, loss of data integrity, or problems with the availability of information [2], [14]. Manufacturing data and the technical documentation and specifications of machines and equipment could be vulnerable to hackers.

Currently the human worker is a machine operator, and machines simply passively follow the operator's commands. The main Industry 4.0 trend will replace this situation with a prognostic monitoring system. Production processes will have to allow for effective production and, at the same time, be flexible owing to changes in customers' demand for specific products.

Industry 4.0 creates new opportunities for companies, but at the same time it creates several challenges stemming from automation and digitisation [15]. The main challenges are listed in Table 3.

Table 3: Main challenges of Industry 4.0 (adapted from Hecklau et al. [15])

\begin{tabular}{|c|c|c|}
\hline CHALLENGES & & CHARACTERISTIC \\
\hline Economic & $\begin{array}{l}0 \\
0 \\
0 \\
0 \\
0 \\
0\end{array}$ & $\begin{array}{l}\text { Shorter product life cycle; } \\
\text { Need to reduce costs to stay competitive; } \\
\text { Customers' expectations for a higher level of customisation and flexibility; } \\
\text { More volatile and heterogeneous markets; } \\
\text { Need for collaboration among companies (strategic alliances with suppliers); } \\
\text { Increased process complexity. }\end{array}$ \\
\hline Social & $\begin{array}{l} \\
\circ \\
\circ\end{array}$ & $\begin{array}{l}\text { Need to update the knowledge of older employees; } \\
\text { Young generation; different social values. Greater balance between work and family life; } \\
\text { Need to qualify employees for more strategic functions. }\end{array}$ \\
\hline Technical & $\begin{array}{l}\circ \\
\circ \\
\circ\end{array}$ & $\begin{array}{l}\text { Extensive IT infrastructures, such as communication networks and internet protocols, need } \\
\text { to be built and implemented; } \\
\text { Exchange of data among partners in a network; } \\
\text { Need to develop standardised interfaces and open architecture, enabling collaborative } \\
\text { work; } \\
\text { Large amount of data storage. }\end{array}$ \\
\hline $\begin{array}{c}\text { Political and } \\
\text { legal }\end{array}$ & & $\begin{array}{l}\text { Governments need to establish legal parameters for the use of large amounts of data } \\
\text { (privacy protection); } \\
\text { The increasing flexibility of work requires regulation for differentiated working hours. }\end{array}$ \\
\hline
\end{tabular}

Through the literature review, the authors [15] agreed that Industry 4.0 would promote a digitised production in which machines and equipment will analyse data and make decisions in real time about maintenance and about the analysis of the production line. However, the discussions in the literature are based on technical concepts, and there is little debate about the training of the professionals who would work in that context.

The main technologies and concepts in the context of Industry 4.0 are listed in Table 4.

Table 5 verifies that the Industry 4.0 theme has been discussed in the scientific environment, and that the main discussion of these articles is focused on the characterisation of Industry 4.0. 
Table 4: Main technologies (adapted from Cordeiro et al. [16])

\begin{tabular}{|c|c|}
\hline Theme & Technology / Concepts \\
\hline \multirow{8}{*}{ Smart factory } & $\begin{array}{l}\text { o Cyber-physical systems (CPS) } \\
\text { o Embedded systems } \\
\text { o Radio frequency identification (RFID) }\end{array}$ \\
\hline & $\begin{array}{l}\text { o Internet of Things (IoT) } \\
\text { o Internet of Services (IoS) }\end{array}$ \\
\hline & Automation \\
\hline & o Modularisation / pre-fabrication \\
\hline & Additive manufacturing \\
\hline & o Product lifecycle management (PLM) \\
\hline & ○ Robotics \\
\hline & o Human computer interaction $(\mathrm{HCl})$ \\
\hline \multirow[b]{2}{*}{ Simulation and modeling } & $\begin{array}{l}\circ \text { Simulation tools } \\
\circ \text { Simulation models }\end{array}$ \\
\hline & $\begin{array}{l}\text { Augmented reality (AR) } \\
\circ \text { Virtual reality (VR) } \\
\circ \text { Mixed reality (MR) } \\
\end{array}$ \\
\hline \multirow{5}{*}{ Scan and virtualisation } & o Cloud computing \\
\hline & o Big data \\
\hline & o Mobile computing \\
\hline & ○ Social media \\
\hline & ○ Digitalisation \\
\hline \multirow{3}{*}{ Plant design/planning of plants } & $\circ$ Plant simulation \\
\hline & Plant network/cross-connecting of plants \\
\hline & Monitoring and analysis of real time data \\
\hline \multirow{3}{*}{ Process management } & Guaranteeing process safety by process monitoring and fault repair \\
\hline & Safeguarding machine data for quality \\
\hline & Preventive maintenance, use of data \\
\hline
\end{tabular}

Table 5: State of the art - Articles in the literature on Industry $\mathbf{4 . 0}$

\begin{tabular}{|c|c|c|}
\hline Article & Year & Abstract \\
\hline $\begin{array}{l}\text { A model based visualization framework } \\
\text { for cross discipline collaboration in } \\
\text { Industry } 4.0 \text { scenarios [11]. }\end{array}$ & 2016 & $\begin{array}{l}\text { The authors point out that, in Industry } 4.0 \text {, the mutual } \\
\text { understanding between experts with varied knowledge is the key } \\
\text { point for the planning and preparation of successful production } \\
\text { scenarios. }\end{array}$ \\
\hline $\begin{array}{l}\text { Analysis of control architectures in the } \\
\text { context of Industry } 4.0 \text { [13]. }\end{array}$ & 2017 & $\begin{array}{l}\text { Industry } 4.0 \text { is a current research topic in the field of production } \\
\text { engineering. }\end{array}$ \\
\hline $\begin{array}{l}\text { Aspects of risk management } \\
\text { implementation for Industry } 4.0 \text { [14]. }\end{array}$ & 2017 & $\begin{array}{l}\text { Industry } 4.0 \text { is a comparatively new method of production } \\
\text { process management. }\end{array}$ \\
\hline $\begin{array}{l}\text { Assembly system configuration through } \\
\text { Industry } 4.0 \text { principles: the expected } \\
\text { change in the actual paradigms [17]. }\end{array}$ & 2017 & $\begin{array}{l}\text { Industry } 4.0 \text { creates what has been called the 'smart factory'. } \\
\text { Cyberphysical systems monitor physical processes and enable } \\
\text { decentralised decisions. }\end{array}$ \\
\hline $\begin{array}{l}\text { Assembly system design in the Industry } \\
4.0 \text { era: a general framework [18]. }\end{array}$ & 2017 & $\begin{array}{l}\text { The latest industrial revolution, known as Industry } 4.0 \text {, uses } \\
\text { machines connected to the internet to manufacture products } \\
\text { designed by the customer, thus having an impact on the design } \\
\text { of the production. }\end{array}$ \\
\hline $\begin{array}{l}\text { Benchmarking of tools for user } \\
\text { experience analysis in Industry } 4.0 \text { [19]. }\end{array}$ & 2017 & $\begin{array}{l}\text { Defines a set of tools to be applied in the Industry } 4.0 \text { scenario } \\
\text { to ensure workers' well-being, safety, and satisfaction, and to } \\
\text { improve the overall performance of the factory. }\end{array}$ \\
\hline $\begin{array}{l}\text { Human-CPS interaction - requirements } \\
\text { and human-machine interaction } \\
\text { methods for the Industry } 4.0[20] \text {. }\end{array}$ & 2016 & $\begin{array}{l}\text { In the design phase in Industry } 4.0 \text {, engineers must deal with } \\
\text { more complexity. In the operational phase, operators and } \\
\text { maintenance technicians must keep production systems up and } \\
\text { running. }\end{array}$ \\
\hline Industry 4.0: A Korea perspective [2]. & 2017 & $\begin{array}{l}\text { Industry } 4.0 \text { needs to maintain the integrity of production } \\
\text { processes. }\end{array}$ \\
\hline $\begin{array}{l}\text { Modelling the flexibility of production } \\
\text { systems in Industry } 4.0 \text { for analysing } \\
\text { their productivity and availability with } \\
\text { high-level Petri nets [21] }\end{array}$ & 2017 & $\begin{array}{l}\text { Industry } 4.0 \text { is characterised by highly flexible production. } \\
\text { Customer-oriented production leads to complex production } \\
\text { systems that need to be modelled and optimised. }\end{array}$ \\
\hline $\begin{array}{l}\text { Towards Lean production in Industry } 4.0 \\
\text { [22] }\end{array}$ & 2017 & $\begin{array}{l}\text { A new paradigm called Industry } 4.0 \text {, or the fourth industrial } \\
\text { revolution, has recently emerged in the manufacturing sector. It } \\
\text { allows the creation of an intelligent network of machines, } \\
\text { products, and components throughout the value chain to result } \\
\text { in a smart factory. }\end{array}$ \\
\hline
\end{tabular}




\subsection{Skills and competencies required by Industry $\mathbf{4 . 0}$}

'Competence' is defined as the set of skills, knowledge, attitudes, and motivations that an individual needs to deal with work-related tasks and challenges [15]. The authors define four types of skills:

- $\quad$ Technical competence: comprises all knowledge and skills related to work;

- Methodological skills: include skills for problem-solving and decision-making;

- $\quad$ Social skills: comprise the skills and attitudes of cooperating and communicating with others;

- Personal competencies: include the values, motivations, and social attitudes of an individual.

'Qualification' is defined as the process of developing the set of skills needed through training and education.

Although the term 'competence' has several definitions in the literature, in this article we will use the definition above, since it includes knowledge and attitude.

In Industry 4.0, workers will need to acquire a whole new set of skills; so new educational systems must be introduced [2].

In Industry 4.0, the tasks will be complex and will require collaboration with machines [23]. The primary task for workers will be the observation and regulation of highly automated complex processes. The skills and abilities of workers will therefore change. Industrial work will become more knowledge-intensive, making cognitive work increasingly relevant in the manufacturing industry.

In a study of production engineering courses in South Africa, the areas that needed curricular adjustments were: advanced data analysis, simulation of real-time systems, and man-machine interfaces [24].

Classical methods of teaching, based on lectures, do not seem to be adequate, especially in the context of developing the necessary skills for future manufacturing environments. Learning factories, which already emphasise interdisciplinarity and an approach close to practice, should react to innovations such as Industry 4.0 to meet the capabilities and skills it requires.

According to the results of a study published by the Fraunhofer Institute, it is possible to identify three skills that are relevant to the future and that are related to the professional in Industry 4.0: dealing with complexity, a capacity for innovation, and flexibility [22].

More and more workers will focus on creative, innovative, and communicative activities. Routine activities, which also include monitoring tasks, will be totally or partially assumed by machines [25].

Although in the bibliographic review we identified that discussions were focused on the characterisation of Industry 4.0, some authors debated aspects of training, skills, and competencies for Industry 4.0. It is important to note that, in Brazil, the Brazilian Association of Engineering Education [26] proposes guidelines for engineering courses that, although they are not based on Industry 4.0, seek to initiate a debate on the need to change the form and content of the subjects.

Some authors have debated the skills and competencies required by Industry 4.0 , as can be seen in the table below.

Table 6: State of the art - Articles in the literature that discuss skills and competencies for Industry 4.0

\begin{tabular}{|l|l|l|}
\hline \multicolumn{1}{|c|}{ Article } & Year & \multicolumn{1}{c|}{ Abstract } \\
\hline $\begin{array}{l}\text { Holistic approach for } \\
\text { human resource } \\
\text { management in Industry }\end{array}$ & 2016 & $\begin{array}{l}\text { The number of jobs with a high level of complexity will increase. The } \\
\text { challenge is to qualify employees to shift their capabilities to more complex } \\
\text { processes. }\end{array}$ \\
\hline $\begin{array}{l}\text { How will change the future } \\
\text { engineers' skills in the } \\
\text { Industry 4.0 framework? A } \\
\text { questionnaire survey [6] }\end{array}$ & 2017 & $\begin{array}{l}\text { Industry 4.0 is one of the most challenging topics for design and the training } \\
\text { of engineers. } \\
\text { The article discusses what skills and experience engineers will need in the } \\
\text { face of Industry 4.0. }\end{array}$ \\
\hline $\begin{array}{l}\text { Learning factory: The path } \\
\text { to Industry 4.0 [27] }\end{array}$ & 2017 & $\begin{array}{l}\text { In Industry 4.0, learning factories have proven to be effective for the } \\
\text { development of theoretical and practical knowledge in an actual production } \\
\text { environment. }\end{array}$ \\
\hline
\end{tabular}




\begin{tabular}{|l|l|l|}
\hline \multicolumn{1}{|c|}{ Article } & Year & \multicolumn{1}{c|}{ Abstract } \\
\hline $\begin{array}{l}\text { Tangible Industry 4.0: A } \\
\text { scenario-based approach to } \\
\text { learning for the future of } \\
\text { production [25] }\end{array}$ & 2016 & $\begin{array}{l}\text { For the effective implementation of Industry 4.0, learning factories, based on } \\
\text { real scenarios, should be implemented. These skills will guide students } \\
\text { towards the new production model. }\end{array}$ \\
\hline $\begin{array}{l}\text { Industrial engineering } \\
\text { curriculum in Industry 4.0 } \\
\text { in a South African context } \\
\text { [24] }\end{array}$ & 2016 & $\begin{array}{l}\text { Industry 4.0 alters the knowledge and skill set requirements for industrial } \\
\text { engineers. } \\
\text { Various functions of industrial engineers will be transformed with Industry 4.0 } \\
\text { Only one university in South Africa has moved towards the adoption of an } \\
\text { Industry 4.0 infrastructure. The authors propose a set of curricular enrichment } \\
\text { items as a basis for curricular reform. }\end{array}$ \\
\hline $\begin{array}{l}\text { Transition towards an } \\
\text { Industry 4.0 state of the } \\
\text { of Technology [10] }\end{array}$ & 2017 & $\begin{array}{l}\text { The learning factory improves academic education for industrial engineering. } \\
\text { The goal is to enable practice-oriented learning in an environment close to } \\
\text { the industrial reality to facilitate the effective transfer of knowledge. These } \\
\text { factories will provide training that focuses on developing the skills and } \\
\text { necessary qualifications for workers to cope with increasing complexity in } \\
\text { industrial learning environments. }\end{array}$ \\
\hline $\begin{array}{l}\text { Requirements for } \\
\text { education and qualification } \\
\text { of people in Industry 4.0 } \\
\text { [28]. }\end{array}$ & 2017 & $\begin{array}{l}\text { The vision of Industry 4.0 will bring not only new approaches, but also the } \\
\text { methodologies and technologies that will have to be introduced in } \\
\text { companies. The transition to such sophisticated production will not be } \\
\text { possible immediately. Employees must be qualified to work in this new } \\
\text { industry model. }\end{array}$ \\
\hline
\end{tabular}

All three previous industrial revolutions influenced not only self-production, but also the labour market and the educational system [28].

Thus, for example, Industry 4.0 will require engineers to analyse a large amount of data and to have a new capability to work on the man-machine interface [24]. One area of Industry 4.0 that is at risk of being greatly affected by the impact of change is the profile of the workforce, especially industrial engineers. The classic profile of engineers' work will increasingly have to dive into the world of information and communication technology to deal with the modelling of processes and complex systems [29].

Engineers in Industry 4.0 should provide and optimise step-by-step guidance for multi-machine operators. Engineers will also have to be open to change, have greater flexibility to adapt to new roles and work environments, and become accustomed to continuous interdisciplinary learning. Engineers will need to develop competencies in the deployment and optimisation of augmented reality systems, skills in advanced analysis for real-time simulation, and taking real-time decisions [24].

Industry 4.0 will lead technical professionals to work continually with new information and a large amount of data that will be interconnected with machines and equipment [10].

Learning factories have proven to be essential for students and professionals in the practical application of production management principles. For Industry 4.0, other skills need to be developed for future managers to work with an increasingly digitised production system [25].

Learning factories appear as highly complex learning environments that enable the development of high quality and autonomous skills, and that are linked to training, education, and the development of learning for Industry 4.0. Baena et al. [27] note that the learning factory seeks to develop experiences through the inclusion of industrial projects in the active learning approach in the curriculum of some engineering programmes, and that preliminary studies have shown a better performance in skills development and knowledge acquisition than through traditional approaches [27].

Several authors identify the themes, skills, abilities, and competencies required for Industry 4.0; these are summarised in the table below. 
Table 7: Capacity / skills / competencies required by Industry 4.0, and their purposes

\begin{tabular}{|c|c|}
\hline Capacity / Skills / Competence & Purpose \\
\hline $\begin{array}{l}\text { Advanced simulation and modelling of } \\
\text { virtual plants [24] }\end{array}$ & $\begin{array}{l}\text { Evaluate a large amount of data from different sources, } \\
\text { optimise production, and make real-time decisions. } \\
\text { Deploy machine data and functionality in the 'cloud' to } \\
\text { facilitate data-driven services to monitor and control } \\
\text { production processes. } \\
\text { - } \\
\text { Optimise industrial systems with simulation (virtual plant). } \\
\text { The real-time nature of the inputs and outputs of Industry } 4.0 \\
\text { makes real-time simulation and plant virtualisation } \\
\text { indispensable in plant operations. }\end{array}$ \\
\hline $\begin{array}{l}\text { Interface between humans and machines } \\
\text { [24] }\end{array}$ & $\begin{array}{l}\text { Programme and act with robots, which must be present } \\
\text { throughout Industry } 4.0 \text {. }\end{array}$ \\
\hline Augmented reality system [24] & - $\quad$ Generate productivity gains. \\
\hline 3D printing [24] & - $\quad$ Manufacturing parts in one step. \\
\hline Computational engineering [24] & $\begin{array}{l}\text { - Understand programming logic to contribute to the process } \\
\text { improvement. }\end{array}$ \\
\hline $\begin{array}{l}\text { Real-time inventory and logistics system } \\
{[24]}\end{array}$ & $\begin{array}{l}\text { - Identify and monitor parts and products in the production } \\
\text { chain. }\end{array}$ \\
\hline Learning factory [10] & $\begin{array}{l}\text { - Enable practice-oriented learning in an environment close to } \\
\text { industrial reality. }\end{array}$ \\
\hline $\begin{array}{l}\text { Interrelations among electrical, } \\
\text { mechanical, and computer components [25] } \\
\text { Statistical methods and data analysis } \\
\text { techniques [25] }\end{array}$ & $\begin{array}{l}\text { Develop innovative strategies, products, and processes to } \\
\text { solve problems of quality. }\end{array}$ \\
\hline Process knowledge [15],[28] & $\begin{array}{l}\text { - Analyse the causes of error and execute quality control of the } \\
\text { output products. }\end{array}$ \\
\hline Efficiency in decision-making [15] & - $\quad$ Solve complex problems more efficiently and in a short time. \\
\hline Analytical skills [9],[15] & - $\quad$ Analyse a large amount of data. \\
\hline $\begin{array}{l}\text { Be able to learn in an autonomous way in } \\
\text { order to deal with unknown situations and } \\
\text { contexts, updating yourself in relation to } \\
\text { advances in science and technology } \\
\text { (permanent updating) [26] }\end{array}$ & $\begin{array}{l}\text { - } \quad \text { Constantly empower (update). } \\
\text { - } \quad \text { Be willing constantly to change / upgrade technology. }\end{array}$ \\
\hline Collaboration at a distance [30] & - $\quad$ Acting as a member of a team that meets virtually. \\
\hline Transdisciplinarity [30] & $\begin{array}{l}\text { - Fully understand at least one discipline, but ability to deal in } \\
\text { a language with a wider range of disciplines. }\end{array}$ \\
\hline
\end{tabular}

Only highly skilled employees will be able to control Industry 4.0 technology [30]. Industry must collaborate with universities.

The skills and qualifications of the workforce will become the key to the success of a highly innovative factory. Benesova and Tupa [28] state that the educational system will be changed from Education 3.0 to 4.0. Education 4.0 will combine real and virtual information [28]. Virtual resources - for example, virtual reality headsets - will be used for teaching. Higher education will be improved - for example, computer science courses will need to include knowledge about process management. Virtual learning environments will be used to transfer knowledge and skills.

There will be a need to create new disciplines and to adapt some existing ones in higher education [28].

It is important that course coordinators and university staff are open to understanding the need for this change; otherwise we risk continuing to train professionals at a higher level but who are limited in their professional performance. Coordinators and teachers should take ownership of this topic and initiate this debate. 


\subsection{Production engineer skills and competencies}

In Brazil, Law 5.194 [31] regulates the exercise of the engineer's activity. The profile of the production engineer, as well as their professional skills and desired skills, follows the guidelines formulated by the National Board of Education [32].

By contrast, some activities will no longer be part of the production engineer's scope [28], especially those involving:

- $\quad$ Production planning;

- $\quad$ Optimising simple repetitive tasks that are executed manually.

Companies face challenges in developing problem-solving skills, failure analysis, ability to cope with constant change, and completely new tasks [10].

Currently, the predominant method of teaching in Brazil is similar to that practised in the 1950s, with large classes and unique silo-ed disciplines. Little progress has been made towards learning based on problems and projects.

This article seeks to provoke this debate in the academic world.

In order to update the teaching of production engineering in Brazil, Abenge [26] elaborated a proposal of national curricular guidelines for engineering courses, with the following objectives:

- $\quad$ Raise the quality of engineering education in the country;

- $\quad$ Allow greater flexibility in the structuring of courses in order to encourage teaching institutions to innovate in their training models;

- $\quad$ Reduce the failure rate in engineering courses.

According to CNE [32], the Brazilian regulation CNE / CES 11/2002 - which is in force, and should deal with the skills and abilities to be developed by production engineers - is based on a core content. Thus the curriculum has focused mainly on the development of contents and practices that are restricted to laboratories, in decontextualised disciplines. This curriculum format no longer meets what is expected of a recent graduate in engineering.

Table 8 shows that the curriculum of production engineering courses has been altered in recent years.

Table 8: Latest revisions of the curricula of production engineering courses

\begin{tabular}{|l|c|}
\hline \multicolumn{1}{|c|}{ University } & $\begin{array}{c}\text { Latest revision of the curriculum of the } \\
\text { production engineering course }\end{array}$ \\
\hline Federal Fluminense University (UFF) [33] & 2017 \\
\hline Federal University of Pernambuco (UFPE) [34] & 2013 \\
\hline Federal University of Rio de Janeiro (UFRJ) [35] & 2015 \\
\hline University of São Paulo (USP) [36] & 2018 \\
\hline Federal University of Rio Grande do Sul (UFRGS) [37] & 2016 \\
\hline University of Campinas (UNICAMP) [38] & 2017 \\
\hline
\end{tabular}

When we analysed the disciplines of these universities according to the categories shown in Table 9, we found that, although the disciplines could be related to Industry 4.0, they deal with traditional processes, technologies, and industry systems. Their curricula do not yet include skills and competencies for Industry 4.0.

We also found that most of the disciplines in the production engineering courses focus on production processes, while only a small number of the disciplines related to computer science and statistics, which are among the pillars of Industry 4.0, appear in production engineering courses. 
Table 9: Major university disciplines that could encompass skills and competencies of Industry 4.0; and the new approach required by Industry 4.0 according to the literature review

\begin{tabular}{|c|c|c|c|c|c|c|c|c|}
\hline Issue & $\begin{array}{c}\text { New approach required by } \\
\text { Industry } 4.0 \text {, according to the } \\
\text { literature review }\end{array}$ & Discipline & UFF & UFRJ & UNICAMP & USP & UFRGS & UFPE \\
\hline \multirow[b]{2}{*}{$\begin{array}{l}\text { Introduction to } \\
\text { production } \\
\text { engineering }\end{array}$} & \multirow[t]{2}{*}{$\begin{array}{l}\text { The role of the production } \\
\text { engineer in Industry } 4.0\end{array}$} & $\begin{array}{l}\text { Introduction to } \\
\text { production } \\
\text { engineering }\end{array}$ & $\mathrm{X}$ & $\mathrm{X}$ & $x$ & $x$ & $\mathrm{X}$ & $x$ \\
\hline & & $\begin{array}{l}\text { Science, technology, } \\
\text { and society in the } \\
\text { context of } \\
\text { production } \\
\text { engineering }\end{array}$ & $X$ & & & & & \\
\hline \multirow{5}{*}{ Statistics } & \multirow{5}{*}{$\begin{array}{l}\text { - Interrelations between } \\
\text { electrical, mechanical, and } \\
\text { computer components } \\
\text { Statistical methods and } \\
\text { data analysis techniques } \\
\text { Develop innovative } \\
\text { strategies, products, and } \\
\text { processes to solve quality } \\
\text { problems } \\
\text { Complex problems need to } \\
\text { be solved more efficiently, } \\
\text { for example by analysing } \\
\text { increasing amounts of data } \\
\text { Article: [25] }\end{array}$} & $\begin{array}{l}\text { Probability and } \\
\text { statistics }\end{array}$ & & $\mathrm{X}$ & & & & $x$ \\
\hline & & $\begin{array}{l}\text { Applied engineering } \\
\text { statistics }\end{array}$ & $x$ & & & & $\mathrm{X}$ & \\
\hline & & $\begin{array}{l}\text { Statistical quality } \\
\text { control }\end{array}$ & & & $\mathrm{X}$ & & & $x$ \\
\hline & & $\begin{array}{l}\text { Simulation } \\
\text { techniques in } \\
\text { production }\end{array}$ & & & & & & $\mathrm{X}$ \\
\hline & & Time series analysis & & & & & & $\mathrm{X}$ \\
\hline \multirow{15}{*}{ Computing } & \multirow{15}{*}{$\begin{array}{l}\text { - } \quad \text { 3D printing; } \\
\text { - Computational } \\
\text { engineering; } \\
\text { Understand programming } \\
\text { logic to contribute to } \\
\text { process improvement; } \\
\text { - Advanced simulation and } \\
\text { virtual plant modelling; } \\
\text { Evaluate a large amount of } \\
\text { data from different } \\
\text { sources, optimise } \\
\text { production, and make real- } \\
\text { time decisions; } \\
\text { Deploy data and machine } \\
\text { functionality in the 'cloud' } \\
\text { to facilitate data-driven } \\
\text { services to monitor and } \\
\text { control production } \\
\text { processes. } \\
\text { Article:[24] }\end{array}$} & $\begin{array}{l}\text { Introduction to } \\
\text { database projects }\end{array}$ & $X$ & & & & & \\
\hline & & $\begin{array}{l}\text { Introduction to data } \\
\text { science and } \\
\text { information }\end{array}$ & & & $X$ & & & \\
\hline & & $\begin{array}{l}\text { Introduction to } \\
\text { computing }\end{array}$ & & & & $x$ & & \\
\hline & & Industrial computing & & & & & $\mathrm{X}$ & \\
\hline & & $\begin{array}{l}\text { Computational } \\
\text { programming applied } \\
\text { to production } \\
\text { engineering }\end{array}$ & & & & & $\mathrm{X}$ & \\
\hline & & $\begin{array}{l}\text { Computer } \\
\text { programming I and II }\end{array}$ & & $X$ & & & & \\
\hline & & Information systems & & & & $\mathrm{X}$ & $\mathrm{X}$ & \\
\hline & & $\begin{array}{l}\text { Computer } \\
\text { programming vs }\end{array}$ & $\mathrm{X}$ & & & & & \\
\hline & & CAD techniques & & $\mathrm{X}$ & & & & \\
\hline & & $\begin{array}{l}\text { Computer-based } \\
\text { manufacturing }\end{array}$ & & & & & & \\
\hline & & $\begin{array}{l}\text { Computer-assisted } \\
\text { projects }\end{array}$ & $x$ & & & & & \\
\hline & & $\begin{array}{l}\text { Computational } \\
\text { production } \\
\text { techniques }\end{array}$ & $x$ & & & & & \\
\hline & & $\begin{array}{l}\text { Information } \\
\text { technology } \\
\text { management } \\
\end{array}$ & & & & & & $\mathrm{X}$ \\
\hline & & $\begin{array}{l}\text { Computer-integrated } \\
\text { manufacturing }\end{array}$ & & & & & & $\mathrm{x}$ \\
\hline & & $\begin{array}{l}\text { Fundamentals of } \\
\text { artificial intelligence }\end{array}$ & & & & & & $x$ \\
\hline
\end{tabular}




\begin{tabular}{|c|c|c|c|c|c|c|c|c|}
\hline Issue & $\begin{array}{c}\text { New approach required by Industry } \\
4.0 \text {, according to the literature } \\
\text { review }\end{array}$ & Discipline & UFF & UFRJ & UNICAMP & USP & UFRGS & UFPE \\
\hline \multirow{20}{*}{$\begin{array}{l}\text { Planning and } \\
\text { production } \\
\text { management }\end{array}$} & \multirow{20}{*}{\begin{tabular}{|l}
$-\quad$ Know the processes \\
Analyse the causes of error \\
and execute the quality \\
control of the output products \\
Intelligent control: runs \\
primarily to physically manage \\
multiple machines or tools \\
through a cloud-enabled \\
platform. \\
- \\
logist-time inventory and \\
- $\quad$ Ensure practice-oriented \\
learning in an environment \\
close to the industrial reality \\
- \\
Remote collaboration \\
Learning factories \\
Articles: [10],[12],[15],[27][28],[30]
\end{tabular}} & \begin{tabular}{|l|} 
Method \\
engineering I and \\
II
\end{tabular} & $x$ & $x$ & & & & $\mathrm{x}$ \\
\hline & & $\begin{array}{l}\text { Studies of } \\
\text { movements and } \\
\text { times }\end{array}$ & $x$ & & & & & \\
\hline & & $\begin{array}{l}\text { New forms of } \\
\text { production } \\
\text { management }\end{array}$ & $x$ & & & & & \\
\hline & & $\begin{array}{l}\text { Modelling and } \\
\text { optimisation of } \\
\text { production } \\
\text { systems } \\
\text { Modelling and } \\
\text { simulation of } \\
\text { production } \\
\text { systems }\end{array}$ & & & & $\mathrm{x}$ & & \\
\hline & & $\begin{array}{l}\text { Organisation of } \\
\text { work in } \\
\text { production } \\
\end{array}$ & & $\mathrm{x}$ & & $x$ & & \\
\hline & & $\begin{array}{l}\text { Productive } \\
\text { systems I and II }\end{array}$ & & & & & $x$ & \\
\hline & & $\begin{array}{l}\text { Industrial } \\
\text { processes } 1,2,3 \\
\text { and } 4\end{array}$ & & & & & & $\mathrm{x}$ \\
\hline & & \begin{tabular}{|l|} 
Production \\
strategy
\end{tabular} & & & & & & $x$ \\
\hline & & $\begin{array}{l}\text { Planning and } \\
\text { production } \\
\text { control I and II }\end{array}$ & $x$ & & & & & \\
\hline & & \begin{tabular}{|l|} 
Strategic \\
industrial \\
planning I \\
\end{tabular} & $\mathrm{x}$ & $\mathrm{x}$ & & & $x$ & \\
\hline & & \begin{tabular}{|l|} 
Facilities \\
planning \\
\end{tabular} & & $\mathrm{x}$ & & & & \\
\hline & & $\begin{array}{l}\text { Techniques for } \\
\text { developing } \\
\text { prospective } \\
\text { scenarios } \\
\end{array}$ & $x$ & & & & & \\
\hline & & Factory project & & & $\mathrm{X}$ & $\mathrm{X}$ & $\mathrm{X}$ & \\
\hline & & $\begin{array}{l}\text { Introduction to } \\
\text { machine design }\end{array}$ & & & & $x$ & & \\
\hline & & \begin{tabular}{|l} 
Understanding \\
manufacturing \\
processes
\end{tabular} & & & $x$ & & & \\
\hline & & \begin{tabular}{|l|} 
Engineering \\
laboratory I \\
\end{tabular} & & & $\mathrm{x}$ & & & \\
\hline & & \begin{tabular}{|l|} 
Integrated \\
management of \\
intelligent cities
\end{tabular} & & & & $x$ & & \\
\hline & & \begin{tabular}{|l|} 
Innovation \\
management
\end{tabular} & & & & & & $\mathrm{x}$ \\
\hline & & \begin{tabular}{|l} 
Production \\
engineering \\
laboratory
\end{tabular} & & & & & & $\mathrm{x}$ \\
\hline & & \begin{tabular}{|l} 
Physical \\
arrangement \\
planning \\
\end{tabular} & & & & & & $\mathrm{x}$ \\
\hline
\end{tabular}

\section{DISCUSSION OF RESULTS}

Although the emphasis in the discussions of most authors is on the characterisation of Industry 4.0, some authors are already starting a debate about the need to revise the content of technical courses, especially those for engineering. 
Analysing the range of production engineering courses at the Universities mentioned in Table 8, and considering the skills and competencies required for Industry 4.0, we find several gaps, which are indicated in Table 9.

It is noted that disciplines need to incorporate and make explicit the skills and competencies of Industry 4.0. The syllabi of the disciplines that currently exist in production engineering courses need to be redesigned to include the skills and competencies required by Industry 4.0. In the bibliographic review, for example, some authors cited the need to implant learning factories [10],[27].

In Brazil, MEC (2002) [39] has not yet issued any guidance about adapting engineering courses that aim to train engineers who are capable of acting in the industry. It is up to the coordinators of the engineering courses to mobilise so that we can form engineers who can contribute to the organisations that are moving towards Industry 4.0.

Teachers should also seek to update themselves to face this new reality.

Although the curricula of the production engineering courses of some of the analysed universities underwent revision in 2017, it is not clear that this revision has taken into account the skills and competencies required by Industry 4.0.

\section{CONCLUSION}

In the light of the literature review, it is apparent that Industry 4.0 will require a reformulation of the choice of subjects in the curricular base of technical courses, especially in production engineering. It is also possible to see that universities need to incorporate this new philosophy so that graduates can work in this new industry, which requires new skills. Even the courses whose curricula have been recently reviewed have not yet incorporated the skills and competencies required by Industry 4.0.

Considering the current syllabi of the production engineering courses of Brazilian universities, and the new skills and abilities required by Industry 4.0 , we conclude that the existing gaps are related to the main technologies involved in Industry 4.0, such as the Internet of Things, cloud computing, communication with sensors and devices, 3D printers, virtual reality, and augmented reality. It is thus necessary for the universities to discuss the structure of the disciplines so that graduates of production engineering courses can work in companies that are implementing the technologies of Industry 4.0.

There is also a clear gap between production engineering courses and the proposed learning factories that are recommended in the literature so that students can experience the reality of Industry 4.0.

The limitations of this study are that it analyses only the curriculum of the production engineering courses of some Brazilian universities.

The academic contribution of this article is to alert universities to the need to discuss the syllabi of the disciplines, with the objective of training professionals who are able to work in and contribute to Industry 4.0.

A suggestion for future studies is to apply this bibliographical survey to other technical courses. In addition, using a survey instrument to raise the perceptions and needs of the teachers and students of production engineering, and the companies that are already applying the concepts of Industry 4.0, would help to improve the academic environment and bring it closer to the industrial environment.

\section{REFERENCES}

[1] Andrade, P.S.A. 2017. A Quarta Revolução Industrial e sua relação com a produtividade atual: Uma revisão da literatura. Monografia apresentada ao Departamento de Administração como requisito parcial à obtenção do título de Bacharel em Administração. Universidade de Brasília, Brasilia.

[2] Sung, T.K. 2017. Industry 4.0: A Korea perspective. Technological Forecasting \& Social Change, 132(C), pp. 40-45.

[3] Hermann, M., Pentek, T. \& Otto, B. 2015. Design principles for Industrie 4.0 scenarios: A literature review. Available at: http://www.snom.mb.tu-dortmund.de/cms/de/forschung/Arbeitsberichte/Design-Principles-forIndustrie-4_0-Scenarios.pdf. Accessed on 29/12/2017.

[4] European Parliament. 2015. Industry 4.0 digitalisation for productivity and growth. Available at: http://www.europarl.europa.eu/RegData/etudes/BRIE/2015/568337/EPRS_BRI\%282015\%29568337_EN.pdf. Accessed on $29 / 12 / 2017$. 
[5] Wahlster, W. Industrie4.0: Cyber-physical production systems for mass customization. German-Czech workshop on Industrie4.0 - Prague, April 11, 2016. Available at: http://www.dfki.de/wwdata/GermanCzech_Workshop_on_Industrie_4.0_Prague_11_04_16/Industrie_4_0_Cyber-

Physical_Production_Systems_for_Mass_Customizations.pdf. Accessed on 09/01/2018.

[6] Motyl, B., Baronio, G., Uberti, S., Speranza, D. \& Filippi, S. 2017. How will change the future engineers' skills in the Industry 4.0 framework? A questionnaire survey. Procedia Manufacturing, 11, pp. 1501-1509.

[7] Gil, A.C. 2010. Como elaborar projetos de pesquisa. $5^{\text {th }}$ ed. São Paulo: Atlas.

[8] Dos Santos, M.T., Vianna, A.S., Jr. \& Le Roux, G.A.C. 2018. Programming skills in the Industry 4.0: Are chemical engineering students able to face new problems? Education for Chemical Engineers, 22, pp. 69-76.

[9] Instituto Nacional de Estudos e Pesquisas Educacionais Anísio Teixeira (INEP). 2015. Índice Geral de Cursos (IGC). Available at: http://portal.inep.gov.br/indice-geral-de-cursos-igc-. Accessed on 23/07/2018.

[10] Karre, H., Hammer, M., Kleindienst, M. \& Ramsauer, C. 2017. Transition towards an Industry 4.0 state of the LeanLab at Graz University of Technology. Procedia Manufacturing, 9, pp. 206-213.

[11] Herter, J. \& Ovtcharova, J. 2016. A model based visualization framework for cross discipline collaboration in Industry 4.0 scenarios. Procedia CIRP, 57, pp. 398-403.

[12] Zhong, R.Y., Xu, X., Klotz, E. \& Newman, S.T. 2017. Intelligent manufacturing in the context of Industry 4.0: A review. Engineering, 3, pp. 616-630.

[13] Meissner, H., Ilsenr, R. \& Aurich, J.C. 2017. Analysis of control architectures in the context of Industry 4.0. Procedia CIRP, 62, pp. 165-169.

[14] Tupa, J., Simota, J. \& Steiner, F. 2017. Aspects of risk management implementation for Industry 4.0. Procedia Manufacturing, 11, pp. 1223-1230.

[15] Hecklau, F., Galeitzke, M., Flachs, S. \& Kohl, H. 2016. Holistic approach for human resource management in Industry 4.0. Procedia CIRP, 54, pp. 1-6.

[16] Cordeiro, G.A., Ordonez, R.E.C., Ferro, R., Nicolela, P.B. \& Stella, B.C. 2017. Etapas para implantação da Indústria 4.0: Uma visão sob aspectos estratégicos e operacionais. XXXVII Encontro Nacional de Engenharia de Produção, Joinville, SC, Brasil, 10-13 October, 2017.

[17] Cohen, Y., Faccio, M., Galizia, F.G., Mora, C. \& Pilati, F. 2017. Assembly system configuration through Industry 4.0 principles: The expected change in the actual paradigms. IFAC PapersOnLine, 50(1), pp. 14958-14963.

[18] Bortolini, M., Ferrari, E., Gamberi, M., Pilati, F. \& Faccio, M. 2017. Assembly system design in the Industry 4.0 era: A general framework. IFAC PapersOnLine, 50(1), pp. 5700-5705.

[19] Peruzzini, M., Grandi, F. \& Pellicciari, M. 2017. Benchmarking of tools for user experience analysis in Industry 4.0. Procedia Manufacturing, 11, pp. 806-813.

[20] Wittenber, C. 2016. Human-CPS interaction - Requirements and human-machine interaction methods for the Industry 4.0. IFAC-PapersOnLine, 49(19), pp. 420-425.

[21] Long, F., Zeiler, P. \& Bertsche, B. 2017. Modelling the flexibility of production systems in Industry 4.0 for analysing their productivity and availability with high-level Petri nets. IFAC PapersOnLine, 50(1), pp. 5680-5687.

[22] Mrugalska, B. \& Wyrwicka, M.K. 2017. Towards lean production in Industry 4.0. Procedia Engineering, 182, pp. 466-473.

[23] Kleindienst, M., Wolf, M., Ramsauer, C. \& Pammer-Schindler, V. 2016. What workers in Industry 4.0 need and what ICT can give - An analysis. 16th International Conference on Knowledge Technologies and Data-driven Business (i-KNOW 2016), Austria.

[24] Sackey, S.M. \& Bester, A. 2016. Industrial engineering curriculum in Industry 4.0 in a South African context. South African Journal of Industrial Engineering, 27(4), pp. 101-114.

[25] Erol, S., Jäger, A., Hold, P., Ott, K. \& Sihn, W. 2016. Tangible Industry 4.0: A scenario-based approach to learning for the future of production. Procedia CIRP, 54, pp. 13-18.

[26] Associação Brasileira de Educação em Engenharia (ABENGE). 2018. Inovação na educação em engenharia Proposta de diretrizes curriculares nacionais para o curso de engenharia. Brasilia. Available at: http://www.abenge.org.br/documentos/PropostaDCNABENGEMEI_CNI.pdf Accessed on 28/02/2018.

[27] Baena, F., Guarin, A., Mora, J., Sauza, J. \& Retat, S. 2017. Learning factory: The path to Industry 4.0. Procedia Manufacturing, 9, pp. 73-80.

[28] Benesova, A. \& Tupa, J. 2017. Requirements for education and qualification of people in Industry 4.0. Procedia Manufacturing, 11, pp. 2195-2202.

[29] Abele, E., Metternich, J., Tisch, M., Chryssolouris, G., Sihn, W., Elmaraghy, H., Hummel, V. \& Ranz, F. 2015. Learning factories for research, education, and training. Procedia CIRP, 32, pp. 1-6.

[30] Institute for the Future - IFTF. 2011. Future work skills 2020. University of Phoenix Research Institute. Available at: http://www.iftf.org/uploads/media/SR-1382A_UPRI_future_work_skills_sm.pdf. Accessed on 29/12/2017.

[31] Presidência da República Casa Civil Subchefia para Assuntos Jurídicos. 1966. Lei Nº 5. 194, De 24 De Dezembro De 1966. Brasília. Available at: http://www.planalto.gov.br/ccivil_03/Leis/L5194.htm. Accessed on 02/06/2018.

[32] Conselho Nacional De Educação (CNE) 2002. Resolução CNE/CES 11, de 11/03/2002. Institui diretrizes curriculares nacionais do curso de graduação em engenharia. Available at: http: //portal.mec.gov.br/cne/arquivos/pdf/CES112002.pdf. Accessed on 21/12/2017.

[33] Universidade Federal Fluminense. Curso de engenharia de produção Available at: http://www.uff.br/?q=curso/engenharia-de-producao/12727/bacharelado/niteroi-. Accessed on 21/12/2017.

[34] Universidade Federal de Pernambuco (UFPE). 2013. Relatório perfil curricular. Available at: https://www.ufpe.br/documents/480103/0/engenharia_producao_perfil_5203.pdf/a1ce1e7d-0ea2-4867-ac361 f0c12182043. Accessed on 24/07/2018.

[35] Universidade Federal do Rio De Janeiro (UFRJ). 2015. Curriculum do curso de graduação em engenharia de produção. Available at: http://www.poli.ufrj.br/graduacao_cursos_engenharia_producao.php. Accessed on 24/07/2018. 
[36] Universidade de São Paulo (USP). 2018. Informações básicas do currículo. Available at: https: / / uspdigital.usp. br/jupiterweb/listarGradeCurricular?codcg=3\&codcur=3083\&codhab=3000\&tipo=N. Accessed on 24/07/2018.

[37] Universidade Federal do Rio Grande do Sul (UFRGS). 2016. Engenharia de produção - Curriculum e grade curricular. Available at: http://www.ufrgs.br/ufrgs/ensino/graduacao/cursos/exibeCurso?cod_curso=322. Accessed on 24/07/2018.

[38] Universidade de Campinas (UNICAMP). 2017. Currículo pleno. Available at: https://www.dac.unicamp.br/sistemas/catalogos/grad/catalogo2018/curriculoPleno/cp102.html. Accessed on 24/07/2018.

[39] Ministério da Educação (MEC) 2002. Referenciais nacionais dos cursos de engenharia - Brasilia. Available at: http://portal.mec.gov.br/dmdocuments/referenciais.pdf. Accessed on 02/06/2018. 